\title{
Impact of Business Communication Determinants on Business Profitability: An Empirical Evidence of Citibank in Greece
}

\author{
Stavros Kalogiannidis, Adjunct Lecturer \\ Department of Business Administration, \\ University of Western Macedonia, Greece \\ ORCiD: https://orcid.org/0000-0002-2337-5775 \\ Dr. Stamatis Kontsas, Assistant Professor \\ Department of Business Administration \\ University of Western Macedonia, Greece
}

Received: Feb. 28, 2021 Accepted: Mar. 22, 2021 Online published: Apr. 15, 2021

doi:10.5296/ijhrs.v11i2.18358ＵRL: https://doi.org/10.5296/ijhrs.v11i2.18358

\begin{abstract}
The aim of this research was to assess the impact of business communication on business profitability using Citibank Greece as the case study. Communication has been for a long time a great tool of improved performance in organizations because it contributes in bridging the gap between the organization and its different stakeholders. However, little focus is normally given on how communication influences profitability of different businesses. Therefore, the aim of this study was to determine the link between business communication and business profitability by employing literature and contextual based research instrument. The research was conducted as a descriptive survey from where data were collected using an online survey questionnaire. The analysis of data was conducted using various expository statistical methods of analysis. Finally, the obtained results strongly suggest that effective communication in business has an obvious and indisputable influence on business profitability and performance.
\end{abstract}

Keywords: communication, performance, business profitability

JEL CODES: E30, M11, M16, M21 


\section{Introduction}

\subsection{Background of the Study}

Kalogiannidis (2020) recognizes business communications as a very important factor in the perfroamnce if empoloyees and in the growth of businesses or organisations. Communication is considered as the main drive of growth or development for the profit-making organizations. The relationship of the business is significant between employees and management. There is a necessity for understanding and interaction of employee-management relations, affecting business productivity and outcomes. According to (Bell \& Martin, 2019), communication is a method, a means to a profitability end, or necessary as the resolution itself. Communication is regarded as an information transmitting process from one individual to another in order to maintain the organizational task. When the command chain is very intense between workers and management, it will finally preserve the business entity. According to (Orel \& Almeida, 2019), business communication is a crucial factor in mobilizing and directing the workforce concerning the achievement of the corporation's objectives or goals. By making understanding, it promotes co-operation and enhances effective productivity.

Intelligent leaders recognize that prosperity is essential for the ultimate straightforward, productive contact between workers and managers. The following means are used to initiate business communication procedures; the sender encodes the message, decodes the channel, input from the receiver, and noise. It is estimated that managers spend over 80 percent of their day interacting with others. Since most of the fundamental planning, organization, leadership, and control of the management process cannot be carried out without effective communication, civilization is unlikely without the knowledge or contact (Heinrich, 2020). More significantly, the business world would not resemble a global village without connection; with connectivity, the worldwide village individuals travel and exchange something. Therefore, engaging with employees in an organsation boosts the the value of job satisfaction and increases the efficiency of the job (Kalogiannidis, 2020).

Kalogiannidis (2020) also indicates that in the case of miscommunication between staff and management, many industrial conflicts arise as collaboration declines, which causes performance evaluation, work promotion, and recognition. Therefore, it is important to emphasize that perhaps the mechanism is significant to enhancing productivity in interactions, attitudes, atmosphere, behavioral and technological attributes. In Jabbarova's (2020) view, psychological communication goes beyond knowledge interpretation but also comprehension and input. In this case communication acts as a souce of motivation for employees to perform better and enhance business growth. This study was therefore concerned with establishing the general impact on communication on bsuinres profitability.

\subsection{Statement of the Problem}

The increased advances of technology have greatly influenced the drives of performance in different businsses or organisations. Communication is among the key factors that have played a key role in influencing business performance in the modern age (Hiller \& Shackelford, 2018). The organization is focused on the employees' understanding. There is 
indeed a major problem of misunderstanding among employers and workers when the contact is different between them. The company organization has many stakeholders, such as workers, staff, vendors, clients, labor unions, government regulators, legislation, respectively (Naidoo \& Gasparatos, 2018). If the investors' contact is a gap, poor communication, there may be a tough time. According to Mironova et al. (2017), several organizational conflicts have been linked to deformation in contact. Despite the commendable role of communicating effectively in enhancing organizational efficiency, as per or executives, staff, and organizations, the communication gap is disadvantageous; it can result in poor quality, compromised interpersonal ties, poor customer service, and unhappy clients. Managers and leaders ought to be excellent leaders and communicators for a company to be successful and increase profitability. This study therefore seeks to assess the influence of communication on business profitability.

\subsection{Research Objectives}

The study aims to explore the impact of business communication on Citibank Greece's business profitability. The specific objectives are as follows:

- To examine communication techniques that influence business productivity .

- To establish the influence of employee feedback on business productivity.

- To examine the effect of successful communication on work efficiency.

\subsection{Research Findings}

- What communication techniques influence business productivity?

- What is the influence of employee feedback on business productivity?

- What is the effect of successful communication on work efficiency?

\subsection{Significance of the Study}

The study findings will help in understanding the general impact of business comamunication on the proftaibility of busineses most especially in the banking sector. Furthermore the results will contribute to the existing knowledge about business communication and business productivity. Such information or literature could be used for reference by different scholars conducting research in the same area of study in the future.

\subsection{Theoratical Framework}

Various models have been sufgested in past communication studies tpo explain how knowledge flows in a society. An review of these models yields some insights into the role of communication in knowledge transmission within a company. Various theories converge to give broader context to organizational communication and the relationship between systems 
and accessible networks, according to reviews of relevant literature in communication. Early studies showed that media has a powerful impact, a phenomenon that has led to media being referred to as the "hypodermic needle" or "Magic Bullet" (Stacks \& Salwen, 2014).

The two-step flow theory, communication theory, and open system theory are examples of communication and management theories and models that attempt to explain how communication occurs in an organization. These models assert that there is selective impact based on social relationships and social categories because communication is a mechanism in which participants establish and exchange knowledge with one another in order to achieve a shared understanding (Littlejohn \& Foss, 2009). Individuals are depicted as psychological devices with their own biases that influence communication flow, and the models seek to account for human behavior. This study was based on the communication theory that consideres effective flow pf knowledge btween bsuiness units as the cbest strategy for enahcing bsuiness prpfotability.

\section{Literature Review}

\subsection{Theoratical Review}

The communication theory was created developred by great scholars namely; Karl Deutch, David Werner, and Robert Asby. In relation to business, communication theory focuses on knowledge flow and structures a sthe major units of analysis in any business.

The developers of this theory were much concerned about the clarity of the channel that carries the message from the sender to the receiver; they argue that there are various distortions along the message channel, which they refer to as noise, that obstruct the flow of information (Littlejohn \& Foss, 2009).

Information as a basis for decision-making in organizations was a concern for Karl and other social scientists. As a result, he argued that effective external and internal communication structures are required to ensure a free flow of information. Decision-making is possible when there is a continuous flow of information within the established structures (Griffin, 2012). Information must be adequate, accurate, relevant, and appropriate in order for this to occur. The basis of an efficient organization is rational decision-making, which translates into productivity and is reliant on a constant flow of information. When there is little or no information flow within an organization, irrational decisions are made(Stacks \& Salwen, 2014).

Karl argued that load capacity, which determines an organization's efficiency in decision-making, is linked to the presence of qualified workers. Communication theory, among other theories, makes serious assumptions by relying too heavily on the use of knowledge as a unit of measurement in rational decision-making. The reality is that other factors and considerations are used to make decisions in a company, and these factors and considerations ultimately contribute to business development and profitability (Griffin, 2012).

The communication theory also asserts that the efficacy of the communication systems and 
networks is often believed, despite the fact that what is written on paper is not always true on the field. Communication theory, on the other hand, has assisted communication scholars in gaining a comprehensive understanding of the complexities of organizational communication (Stacks \& Salwen, 2014).

\subsection{Empirical Review}

Since the beginning of civilization, communication evolvement has always been the fundamental reformation factor in building a human race courteous association. Similarly, to guarantee the achievement of practical business results from a profit-making organization, there exists no replacement of effective communication in business. Therefore, employees need to maintain a significant connection with peers, coworkers, and top management. Communication is often a mechanism in which one or even more persons in one organization share thoughts, opinions, ideas, and suggestions. An important aspect of organizational success is coordination. The role of the management process is communication. If the correspondence with the lower or mid-level leadership is missing in the upper executives, the company would not be adequate (Köseoglu et al., 2020). It is necessary to establish coordination among the organization's stakeholders to execute the management planning functions, coordinating, encouraging, controlling, and directing. Communication is a key skill hence the need for effective leadership through which managers build and sustain employee relationships to better perform the required daily tasks.

Organization Communication has been the arrangement of interactions between administrative bodies that operate. In today's organizations, data can now be distributed more rapidly than in the past. Each entity then becomes an open structure with communication, containing reciprocity, including its surroundings (Griffin, 2012). The management's responsibility is to coordinate support structures throughout the global strategy to express their requirements and frustrations. This should keep the business running effectively and make many more employees be the firm's most outstanding asset (Simsa et al., 2019).

\subsubsection{Communication and Business Productivity}

Company contact is very critical to the company's success. For the performance of the firm, the engagement of two individuals is vital. It generates an emotional problem when upward or downward contact does not occur in the company organization. The effectiveness of the organization primarily depends on collaboration, focus, and contact between subordinates. The business organization depends on output or efficiency (Elston et al., 2018). If the level of production is poor, there is also legislation on organizational efficiency. Owing to shifts in workers' needs in today's organizations, an atmosphere that stimulates and meets far more than just physiological and safety needs should be provided. Output as opposed to priorities and goals.

However, according to Hyväri (2016), it was not just the product of firm success; it was a constant process of various activities. Capacities were the initiative to do tasks, which are also the procedures leading to its success. Performance measurement was seen by Argenti (2018) as a complex activity, complicated, demanding, and significant. The level of 
performance is often a function of the enterprise operations' effectiveness and efficiency, so performance assessment is the method of quantifying an organization's efficiency and effectiveness.

The basic component of global capitalism is contact or negotiation skills. Among the involved parties, communication skills are essential. Information sharing helps to extract all latent talents from its institution's subordinates. In the area of business enterprise, professional communication plays an important role (Bowen, 2020). In a company, power flows through effective communication, which applies through information exchange possibilities, then evolves and ultimately enters and is retained in an organizational sense. To accomplish the organization's particular goals, knowledge sharing is necessary for superiors and employees. Management performance relies on using strategic practices such as people, computers, capital market methods, and materials. To accomplish one such organization's objectives, it is necessary to organize, coordinate, lead, and monitor, and marketing strategy is crucial for the effective execution of the strategy implementation (Hyväri, 2016). Communication also plays a key role in mantining businesses especially in times of uncertainity or crisis. For example, the COVID-19 pamndemic left many businesses with no other option but to practice modern forms of communication as the only way of maintaining higher business performance (Kalogiannidis, 2020). Organization based communication has greatly imporoved coordination or interactions between administrative bodies and employees or clients which has a positive impact on business.

\subsubsection{Managing Communication in Business}

Communication is considered the most effective method for integrating and organizing the activities of specialized units at various levels in business. Understanding the communication mechanism isn't enough to handle communication in an enterprise. Managers must be good communicators themselves, and they must inspire their staff to do the same. They will effectively organize and manage the operations of their organizations. According to Kalogiannidis \& Papaevangelou (2020), managers have the ability to effectively communicate their strategies, actions, goals, and job guidance to those who work with them at all levels. As a result, these abilities are critical for business executives to fulfill their managerial duties. Interpersonal communication, community communication, and internal communication are all aspects of such communication organizations (i.e. the exchange of messages among organizational members). Every company has a structured communication mechanism in which the flow of information is regulated by the company's official structure. Formal networks are organized in accordance with the organization's different levels, branches, departments, and job responsibilities (Griffin, 2012).

The formal channels managers and workers use to convey official information are the lines of authority that connect the chain of command in an organization map. Phone calls, memos, reports, staff meetings, department meetings, conferences, the business newsletter, and official notices are all examples of formal communications (Kalogiannidis, 2020).Vertical communication that is effective offers information about plans, schedules, politics, and practices to people on the lower level, as well as input to upper level management to decide 
the responses to messages sent downward (Kalogiannidis, 2020). The effectiveness of horoxaonatl communication in business is also key to growth andincreased profitability since ot encouranges flow of important information among persons holding the same position in an organization or business (Kalogiannidis \& Papaevangelou, 2020)

\subsubsection{Banking, Capital Markets and Advisory Communicating Aspects}

Citi Bank has used a number of communication platforms to boost its profitability in the banking and capital markets sectors (Citibank n.d). Citibank leverages the scope of our unparalleled global network to include debt capital raising, merger and acquisition (M\&A), and equity-related strategic funding strategies, as well as issuer services, and ensure our client experience stands above all else (Chen et al., 2017). Citi Bank utilizes effective communication with customers to assit them grow their bsuiness, resulting in more employment and economic value at home and in communities around the world. Citi Bank has reassessed Greek minorities and is satisfied that, after activities in 2018, there was no statistically substantial difference in the amounts paid to Greek minorities and non-minorities at Citi. As a result of our analysis, we made necessary pay changes in the 2019 salary period. Although we know that we still have a long way to go, we are pleased with our progress (Citibank n.d). Citi Bank understands that effective communication with employees during their careers at the bank, as well as a dedication to becoming an organization with values that customers can be proud of, are critical to the company's success. Citi Bank is redefining how it interacts with customers, hires, and develops talent as part of a plan to boost profitability and, as a result, achieve continued growth (Citibank n.d). Citi Bank also uses information gathered from communications with various stakeholders to identify the bank's issues and areas for change.

\section{Methodology}

The study was based on a descriptive research design. Based on the creation of the subject, a questionnaire was developed on the feasibility of successful business communication by individual crucial components representing the company's entire prevalence. A questionnaire was used to gather data from the workers. They were free to respond to several of the indicators related to the impact of communication in terms of their perspectives directly and indirectly.

\subsection{Target Population and Sample Size}

Sampling is preferred to avoid dealing with the entire population of workers that is very costly and time consuming. So a variety of the chosen population was a targeted at five merchant outlets around the country. A collection of 150 questionnaires was submitted and distributed among the 150 employees selected. They were brought back after a short period. Only 120 workers were able to return the questionnaire within the timeframe. Data analysis was performed on the information gathered from subordinates employing descriptive statistical techniques.

\subsection{Data Collection}


Data were collected from the workers of Citibank Greece through an online survey quaestionnaire. Personal details, like age, work experience and knowledge on the impact of communication on business profitability were gathered throughout the checklist information section in the questionnaire.

\subsection{Data Analysis}

The collected data were sorted, coded and then imported to SPSS for analysis. The final results were presented in tables and pie charts. Interpretation of the results was made based on the descriptive statistics and especially frequencies and percentages.

\section{Findings}

This section is devoted to the analysis and presentation of the research findings.

\subsection{Demographic Characteristics}

The diffrent demographic or background characteristics of study participants are presented in table 4.1

Table 4.1. Demographic Characteristics

\begin{tabular}{|l|l|l|}
\hline \multicolumn{2}{|l|}{ Background Characteristics } & Frequencies \\
\hline Sex of respondents & 78 & 65.0 \\
\hline Male & 42 & 35.0 \\
\hline Female & \multicolumn{2}{l|}{} \\
\hline Age distribution & 32 & 27.0 \\
\hline Below 25 years & 50 & 41.0 \\
\hline 21 to 30 years & 26 & 22.0 \\
\hline 41 to 50 years & 12 & 10.0 \\
\hline 51 to 60 years & & \\
\hline Years spent working in the bank & 17 & 14.2 \\
\hline 0 to 4 years & 51 & 42.5 \\
\hline 5 to 8 years & 37 & 30.8 \\
\hline 9-12 years & 15 & 12.5 \\
\hline 12 years and above & & \\
\hline Qualification & 55 & 19 \\
\hline Bachelors degree & 136 & 47 \\
\hline Masters degree & 98 & 34 \\
\hline PhD & $\mathbf{1 2 0}$ & $\mathbf{1 0 0}$ \\
\hline Total & & \\
\hline
\end{tabular}

Source: Survey (2020)

The results in table 4.1 show that the majority of the respondents $(65 \%)$ were male while only $35 \%$ are female. Furthermore the majority of the participants $(41 \%)$ belonged to the age 
range 21 to 30 years, $27 \%$ are below 25 years, $22 \%$ are between 41 to 50 years while the smallest number of respondents $(10 \%)$ belonged to the range of 51 to 60 years. The results show that the largest number of respondents $(42.5 \%)$ had served 5 to 8 years in the bank, $30.8 \%$ of participants had worked for 9 to 12 years, and the smallest number of respondents (12.5\%) had served for 12 years or more. Several qualification parts show that $29 \%, 35$ individuals, are undergraduates, and the remaining $71 \%, 85$ participants, are degree holders.

\subsection{Descriptive Analysis}

The study sought to establish the different communication techniques that influence business productivity and the results are presented in figure 4.1

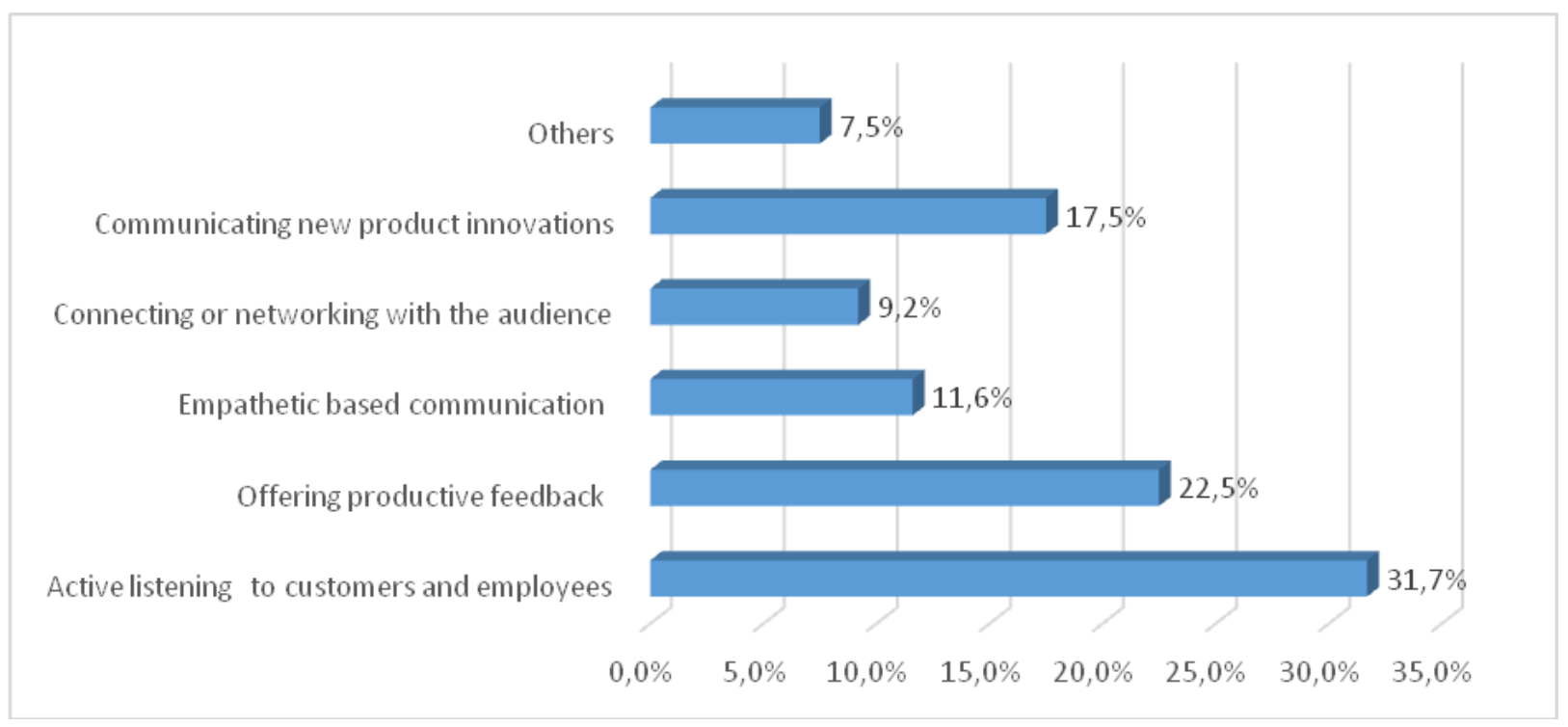

Figure 4.1. Communication techniques that influence business productivity

Source: Survey (2020)

The majority of the respondents $(31.7 \%)$ in figure 4.1 indicated that active listening to customers and employees is the most important communication technique that can help to enhance business profitbailility. Active listening is consists of the company management paying much attention to needs or demands of customers and employees which acts as a basis fir for proper decision making towards improved profitability. 22.5\% of the respondents indicated that offering productive feedback also helps to enhance business profitability. Kalogiannidis (2020) indicates that most feedback from customers helps to make different changes in the quality or quantity of the products on the market, which tends to increase sales and revenues collected from those particular products. $17.5 \%$ indicated that communicating new product innovations is also important in enhancing business profitability, $11.6 \%$ mentioned empathetic based communication, while the smallest number of respondents (9.2\%) indicated that connecting or networking with the audience is the best communication technique to improve the levels of profitability in any business. It is important to note that techniques such as empathetic communication, play a key role in improving the levels of trust in motivating employees to remain commited to achieving the different goals and objectives 
of the organisation.

Another aim of the study was to explore the influence of employee feedback on business productivity since it could help in establishing the impact of communication on business profitability. The results obtained after analysis are presented in figure 4.2

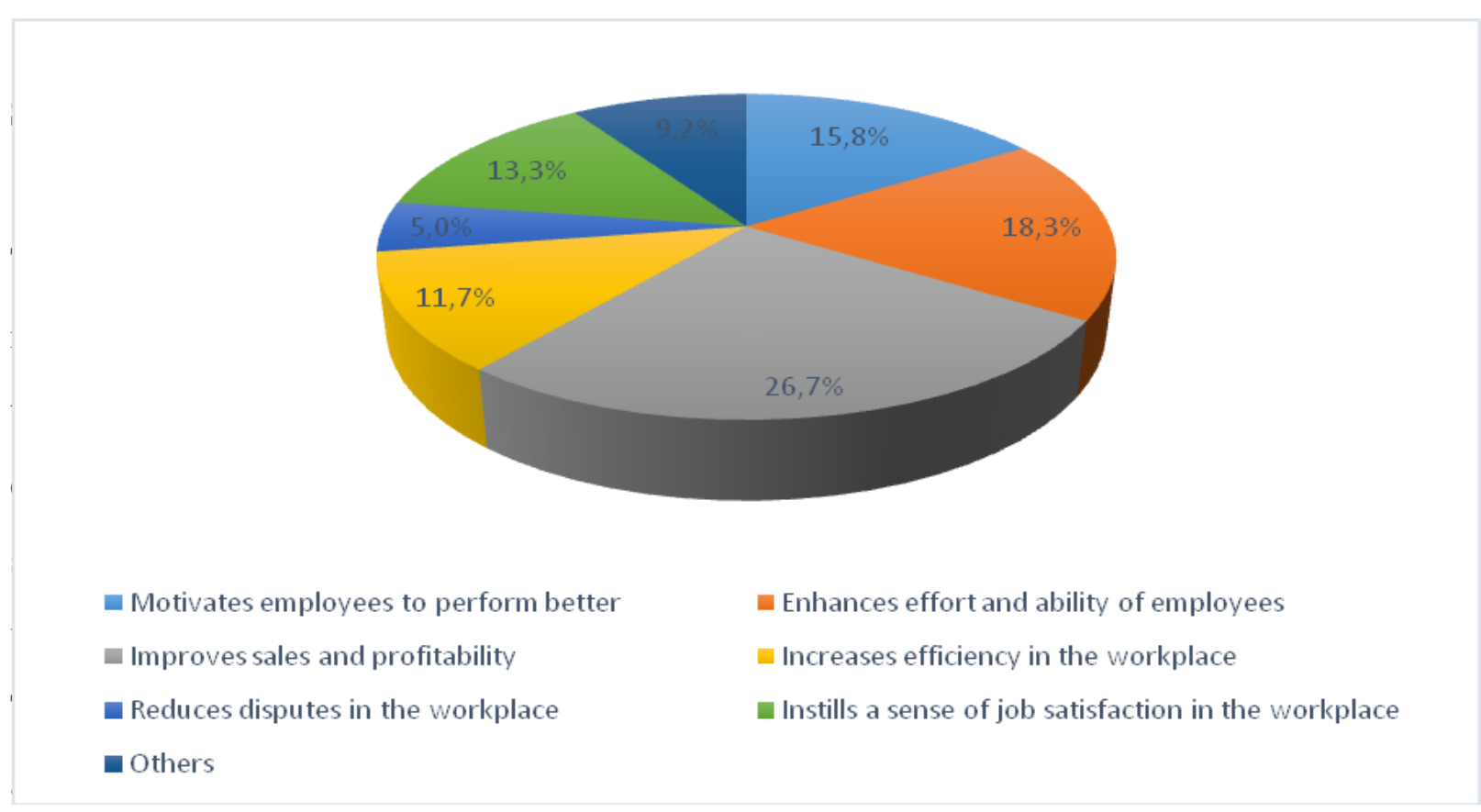

Figure 4.2. Influence of employee feedback on business productivity

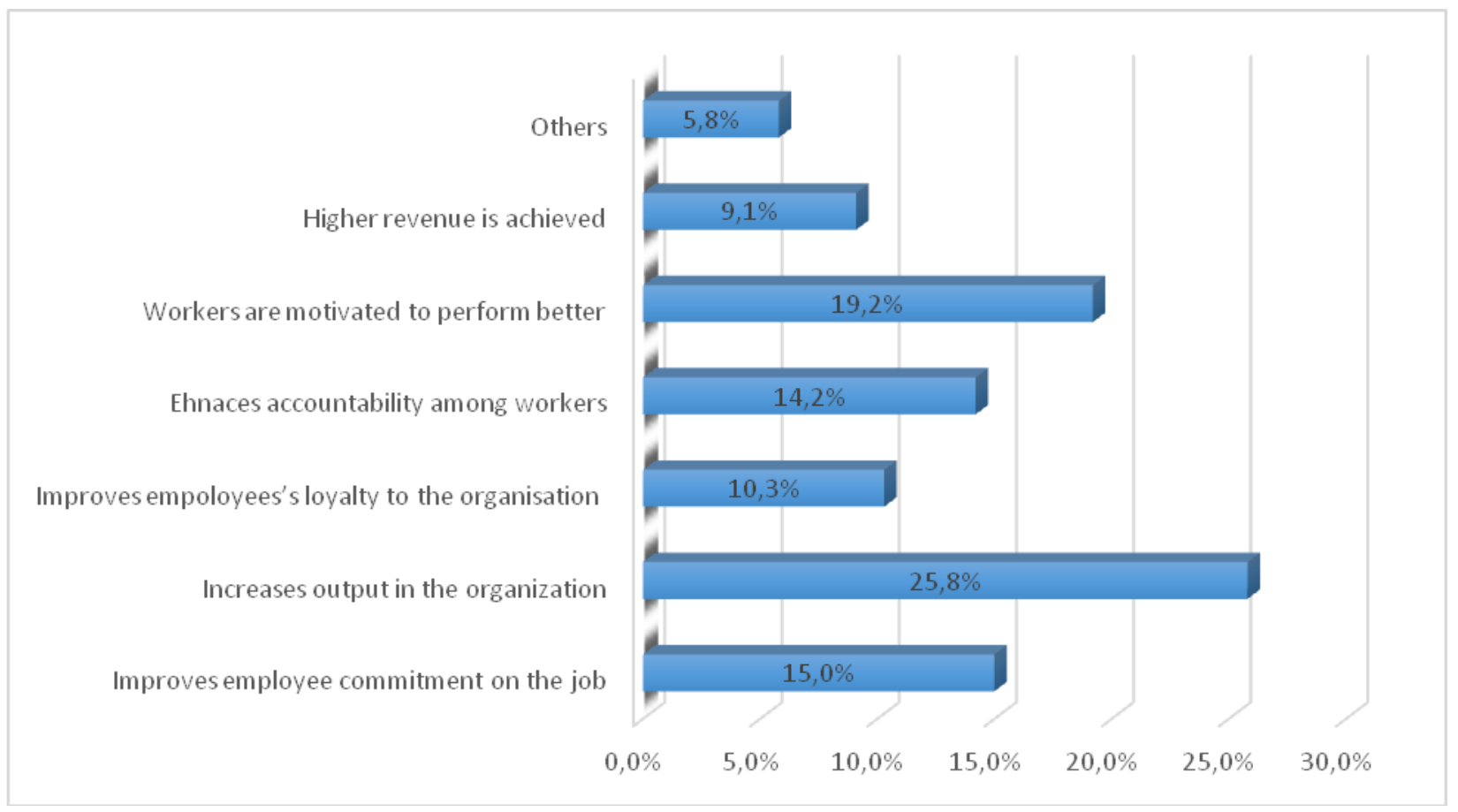

Figure 4.3. Effect of successful communication on work efficiency

Source: Survey (2020) 
The majority of the participants $(25.8 \%)$ in figure 4.3 indicated that successful communication increases output in the organization. This is an indication that the mode of communication used in a particular company has a great infleunce on the final product outcomes since it also infleunces that ability of employees to perform better. This is similar to 19.2\% who indicated that workers are easily motivated to perform better. Furthermore, $14.2 \%$ indicated that it enhaces accountability among workers, $10.3 \%$ indicated that it improves empoloyees's loyalty to the organization, while the smallest number of respondents $(5.8 \%)$ mentioned other effects of successful communication such as increased competitive advantage on the market and improved reputation in the industry. It is important to note that with proper communication in a company especially with employees and customers, higher effeciency of employees is guaranteed. This further has a positive impact on a company's reputation based on the postive recommendations from existing customers or employees, which consequently enhances business profitability.

\section{Discussion}

The findings confirm that commuminaction has a big impact on the proftibaility of a business since it influences the ability of employees to perform better (Kalogiannidis, 2020). Communication also infleunces the ability of customers to continuously purchase a partuclar production the market and this infleunces levels of sales and business profitability in the long run. Employees appear to be motivated to accomplish the objectives of the company if they can interact precisely with either the entire organization. It also helps them feel safe and relaxed at work. A successful communication system gives self-satisfaction to workers, as their success is well understood and valued. It often provides a sense of bits of help to identify a product. It strengthens the organizational climate as accountability and dignity prevail within the company. Good contact also strengthens ties not only with upper executives but also with colleagues and peers. It helps stimulate the employee's job strength to proceed to the objective of the company (Bowen, 2020). It is evident from the above study that successful business communication has a substantial impact on employee morale and job satisfaction and, therefore, indirectly affects the company's competitiveness and efficiency. The thoughts and desires of the workers are expressed seamlessly through feedback gathered by the employer, which then can be used to make positive changes in the business (Kalogiannidis, 2020). The study findings comfirm that in the absence of effective communication in an organisation, a decline in sales or revenues collected is likely to happen. It is therefore important for the different players in the banking industry and other business to focus on improving the mode of communication so as to enhance business profitability.

\section{Conclusion and Recommendations}

Verbal teamwork is indeed an inextricable and binding operation of individuals, groups, organizations, and cultures in all modern populations. In this report, four principal measures of successful communication are addressed: compassion, responsiveness, help and interpersonal skills, and their relationship to work performance and business profitability. In today's organizations, leading to changes in workers' customer behavior, the atmosphere should be created to promote and meet far more than just safety and physiological needs. 
In cases where remuneration is based on efficiency, the total sum of remuneration is based on a combination of the measurement of the person's and the profitability unit's performance, as well as the institution's overall results, and when determining individual performance, financial and non-financial criteria are considered. As a result, the training measures that are the focus of this decision are specifically necessary to meet the requirements imposed by the company's business plan and would have been incorporated in any case even if help had not been given. In order to keep the public informed about the risk and the steps taken, the crisis unit will establish its communication strategy in accordance with the case at hand.

Having sufficient preliminary contact with stakeholders, where possible, and, in particular, when information is released in relation to a specific commercial brand or name, are among the communication skills acquired by the crisis team. As a result, the preparation steps that are the focus of this decision are specifically needed to meet the company's profitability strategy's requirements, and would have been introduced in any case even if help had not been provided. Promoting human resource development as a business strategy (management and micro-economic dimension), for example, by benchmarking good practice in firms in terms of productivity, or by using metrics to bring out the cost of investment and the benefits, for both firms and staff.

Other considerations, apart from financial performance, should be considered in order for remuneration policy to be in line with the financial institution's goals, principles, and long-term interests, such as compliance with the financial institution's processes and controls, as well as compliance with the criteria regulating the relationship with clients and investors. On the supply side, the investor must conduct a thorough examination not only of the collateral being offered (as a lender would), but also of the whole business plan in order to estimate the likelihood of benefit and the risks associated with the investment.

\section{References}

Argenti, J. (2018). Your organization: What is it for?: challenging traditional organizational aims. Routledge. https://doi.org/10.4324/9781351258609

Bell, R. L., \& Martin, J. S. (2019). Managerial communication for organizational development. Business Expert Press.

Bowen, M. (2020). Management Communication Research On Futong Group Communication Technology (Thai) Company (Doctoral dissertation, Siam University).

Chen, Z., Li, Y., Wu, Y., \& Luo, J. (2017). The transition from traditional banking to mobile internet finance: an organizational innovation perspective-a comparative study of Citibank and ICBC. Financial Innovation, 3(1), 1-16. https://doi.org/10.1186/s40854-017-0062-0

Citibank: Banking, Capital Markets and Advisory. Available online on https://www.citibank.com/icg/bcma/

Elston, T., MacCarthaigh, M., \& Verhoest, K. (2018). Collaborative cost-cutting: Productive efficiency as an interdependency between public organizations. Public Management Review, 20(12), 1815-1835. https://doi.org/10.1080/14719037.2018.1438498 


\section{Ml Macrothink}

International Journal of Human Resource Studies ISSN 2162-3058 2021, Vol. 11, No. 2

Griffin, E. A. (2012). A first look at communication theory/Em Griffin. New York: McGraw-Hill.

Heinrich, T. N. (2020). Social Software Impact Analysis on Management and Leadership Style in Two Countries (Doctoral dissertation, University of Phoenix).

Hiller, J. S., \& Shackelford, S. J. (2018). The firm and common pool resource theory: Understanding the rise of benefit corporations. American Business Law Journal, 55(1), 5-51. https://doi.org/10.1111/ablj.12116

Hyväri, I. (2016). Roles of top management and organizational project management in the effective company strategy implementation. Procedia-Social and behavioral sciences, 226, 108-115. https://doi.org/10.1016/j.sbspro.2016.06.168

Jabbarova, A. (2020). Psychological characteristics of listening activities. Архив Научнылх Публикаций JSPI, 1-14.

Kalogiannidis, S., Melfou, K., \& Papaevangelou , O. (2020). Global Marketing Strategic Approaches on Multi National Companies Product Development . International Journal of Scientific Research and Management, 8(12), 2084-2090. https://doi.org/10.18535/ijsrm/v8i12.em08

Kalogiannidis, S. (2020). Impact of Effective Business Communication on Employee Performance. European Journal of Business and Management Research, 5(6). https://doi.org/10.24018/ejbmr.2020.5.6.631

Kalogiannidis, S. (2021). The Effects of Total Quality Management Practices and Marketing on Performance of SMEs. A Case of Selected Manufacturing Industries, Greece. Business Management and Strategy ISSN 2157-6068, Vol. 12, No. 1, 48 to 62. https://doi.org/10.5296/bms.v12i1.17995

Kalogiannidis, S., \& Papaevangelou, O. (2020). Impact of Business Communication on the Performance of Adult Trainees. International Journal of Academic Research in Progressive Education and Development, 9(3), 213-222. https://doi.org/10.6007/IJARPED/v9-i3/8154

Kalogiannidis, S., Mavratzas, S. (2020). Impact of marketing mix strategies effective product development issues in MNCs/Retail. International Journal of Business Marketing and Management (IJBMM) Volume 5 Issue 12 December 2020, P.P. 118-125. ISSN: 2456-4559.

Köseoglu, M. A., Altin, M., Chan, E., \& Aladag, O. F. (2020). What are the key success factors for strategy formulation and implementation? Perspectives of managers in the hotel industry. International Journal of Hospitality Management, 89, 102574. https://doi.org/10.1016/j.ijhm.2020.102574

Littlejohn, S. W., \& Foss, K. A. (2009). Encyclopedia of communication theory (Vol. 1). Sage. https://doi.org/10.4135/9781412959384

Mironova, O., Polyakova, O., \& Ushkov, F. (2017). Impact of compelled contacts on psychosomatic disorders of employees of organizations. Economic and social development: 


\section{Macrothink}

International Journal of Human Resource Studies

ISSN 2162-3058 2021, Vol. 11, No. 2

Book of Proceedings, 878-885.

Naidoo, M., \& Gasparatos, A. (2018). Corporate environmental sustainability in the retail sector: Drivers, strategies, and performance measurement. Journal of Cleaner Production, 203, 125-142. https://doi.org/10.1016/j.jclepro.2018.08.253

Orel, M., \& Almeida, M. D. M. A. (2019). The ambience of collaboration in coworking environments. Journal of Corporate Real Estate. https://doi.org/10.1108/JCRE-12-2018-0050

Simsa, R., Rameder, P., Aghamanoukjan, A., \& Totter, M. (2019). Spontaneous volunteering in social crises: Self-organization and coordination. Nonprofit and Voluntary Sector Quarterly, 48(2_suppl), 103S-122S. https://doi.org/10.1177/0899764018785472

Stacks, D. W., \& Salwen, M. B. (Eds.). (2014). An integrated approach to communication theory and research. Routledge. https://doi.org/10.4324/9780203887011

\section{Copyright Disclaimer}

Copyright for this article is retained by the author(s), with first publication rights granted to the journal.

This is an open-access article distributed under the terms and conditions of the Creative Commons Attribution license (http://creativecommons.org/licenses/by/4.0/). 